Onder redactie van:

Prof. mr. dr. B.M.E.M. Schols

Prof. mr. dr. W. Burgerhart

Prof. mr. dr. F.W.J.M. Schols

Mr. F.M.H. Hoens

Mr. G.A. Tuinstra

Mr. J.Th.M. Diks

Mr. M.J.P. Schipper

Mr. dr. N.V.C.E. Bauduin

Mr. E.C.E. Schnackers

Mr. dr. J.W.A. Rheinfeld

\title{
Advotip
}

Erfrecht voor de advocaat

\section{Besmettelijke ziekten, heldenberoepen en noodtestamenten}

Zware tijden, dat spreekt voor zich. Maar ook tijden waarin men zich de vraag stelt welke bijzondere juridische regelingen in werking treden. Voor het erfrecht is dat artikel 4:102 BW:

'Op plaatsen waar voor de erflater het normale verkeer met een notaris of bevoegde consulaire ambtenaar verboden of verbroken is als gevolg van rampen, crises, gevechtshandelingen, besmettelijke ziekten of andere buitengewone omstandigheden, kan hij een uiterste wil maken ten overstaan van een Nederlandse consulaire ambtenaar, ook indien deze niet krachtens de gewone regelen bevoegd is, of de burgemeester, de secretaris of een wethouder der gemeente, een kandidaat-notaris, een advocaat, een officier van de krijgsmacht of van een gemeentelijke of regionale brandweer, of een daartoe door de minister van justitie bevoegd verklaarde ambtenaar.' (Curs. BS)

Hier zullen we echter weinig mee opschieten, de regeling van noodtestamenten als buitengewone testamentsvorm is allesbehalve soepel toepasbaar, waardoor er in de praktijk zo goed als nooit gebruik van werd gemaakt. Denk bijvoorbeeld aan de twee getuigen, maar vooral ook aan de erfrechtelijke onwetendheid in het algemeen. Zo merkt H.J. de Jonge, 'Noodtestamenten en artikel 4:61 BW', Tijdschrift Erfrecht 2019 nr. 2 op:

'Uit gegevens van het CTR, die aan mij op verzoek zijn verstrekt, is gebleken dat er in het verleden slechts één noodtestament is opgesteld. Dit betrof een testament gemaakt ten overstaan van een gezagvoerder in een vliegtuig.'

En dat was waarschijnlijk geen 'echte nood':

'Volgens de Koninklijke Notariële Beroepsorganisatie (hierna: KNB) was er in dit geval geen sprake van een noodsituatie, maar betrof het een student (notarieel recht) die dit testament bij wijze van experiment heeft opgesteld.'

De Jonge verwijst dan ook naar artikel 4:108 BW:

'Een uiterste wil die op een in een der artikelen 98, 101, 102 en 104 vermelde wijze, doch niet onder de daar aangegeven omstandigheden is gemaakt, is, indien de 
erflater binnen zes maanden daarna overlijdt, niet van rechtswege nietig, doch vernietigbaar.' (Curs. BS)

Want in artikel 4:101 BW lezen wij:

'Zij die zich op een reis aan boord van een zeeschip of luchtvaartuig bevinden, kunnen een uiterste wil maken ten overstaan van de gezagvoerder of de eerste officier, of bij gebreke van deze personen ten overstaan van hem die hun plaats vervult.' (Curs. BS)

Let bij het echte noodtestament ook op de termijn van zes maanden voor herstel. Wat er ook van zij: de formele regeling van het noodtestament is goed bedoeld, maar zal in de praktijk weinig zoden aan de dijk zetten, de materiële geest wellicht wel. Al is het maar, zoals aangestipt, dat in echte nood de niet-juristen de regeling vanzelfsprekend ook niet zullen kennen. Een andere route brengt ons wellicht het 'echte' materiële noodtestament, te weten het notariële depottestament, te vinden in artikel 4:94 en artikel 4:95 BW. Waar we in artikel 4:95 lid $5 \mathrm{BW}$, dat uitdrukkelijk handelt over de onderhandse uiterste wil die bij de notaris gedeponeerd dient te worden in een testeerceremonie, lezen:

'Wanneer de erflater verklaart dat hij door een met name door hem genoemde, na de ondertekening van de uiterste wil opgekomen oorzaak verhinderd wordt de akte van bewaargeving te ondertekenen, vervangt die verklaring zijn ondertekening van de akte van bewaargeving, mits zij daarin wordt opgenomen.' (Curs. BS)

Ik begrijp dat dit volgens de voorzitter van de KNB kan betekenen dat de notaris de tekst aanlevert voor het opstellen van de onderhandse akte en dat deze akte zichtbaar voor de notaris (bijvoorbeeld via een raam of audiovisuele verbinding) dient te worden getekend.

Ik realiseer me dat in de letterlijke wettekst staat 'na ondertekening van de uiterste wil opgekomen oorzaak' maar daar zal een rechter in 'oorlogstijd' weinig problemen mee hebben. Nood breekt immers wet! Maar veel belangrijker is dat mensen in deze moeilijke tijden verantwoordelijkheid durven nemen en creatieve oplossingen durven bedenken. Ofwel: complimenten KNB! In deze tijden is behoefte aan helden en heldenberoepen, aan mensen die hun nek durven uit te steken!

Afgelopen zondag verscheen nog een aanvullend bericht van de zijde van de KNB:

'De KNB vindt, net als de Vereniging van Estate Planners in het Notariaat (EPN), het juridisch-dogmatisch beter als de wet hiervoor meer mogelijkheden biedt, maar de KNB sluit die binnen de bestaande wettelijke mogelijkheden niet per definitie uit. $\mathrm{Zij}$ is van mening dat notarissen een belangrijke maatschappelijke rol vervullen in het rechtsverkeer en in voorkomende gevallen, zoals deze de plicht hebben mensen te helpen. Dit geldt des te meer in een noodsituatie waarmee Nederland en dus ook het notariaat zich geconfronteerd weet. Dat de geldigheid van testamenten achteraf ter discussie gesteld kan worden bij de rechter, doet daar niets aan af, zo vindt de KNB. De beroepsorganisatie stelt dat het beter is dat notarissen achteraf het verwijt krijgen dat ze iets gedaan hebben, dan dat hen verweten wordt niets gedaan te hebben. De KNB zal notarissen tegen wie in de toekomst mogelijk een dergelijke rechtszaak wordt aangespannen, daarom voluit steunen.' (Curs. BS)

Mooie woorden: beter iets, dan niets! Het is een tijd waarin het doel immers (bijna) alle (erfrechtelijke) middelen heiligt. En nog belangrijker: het testeer-skypen versterkt ook nog het bewijs dat hetgeen op het in bewaring gegeven erfrechtelijke papier staat daadwerkelijk de uiterste wil van betrokkene is. Ter voorkoming van misverstanden: de 
erflater hoeft de uiterste wil niet, zoals de klassieke holograaf, eigenhandig te schrijven, want blijkens artikel 4:95 lid 2 BW volstaan mechanische middelen.

Blijkens artikel 4:95 lid 3 BW moet (onder meer) dit wel nog gebeuren:

'Een onderhandse uiterste wil wordt door de erflater aan de notaris ter hand gesteld.' (Curs. BS)

En dat zal ook nog wel lukken.

Wel is dit het moment om te gaan nadenken en een goed doordachte passeerregeling voor de toekomst te ontwikkelen (al dan niet met terugwerkende kracht) en om 'bij wijze van spreken' passeercabines en medische maanmanpakken voor de notariële garderobe aan te schaffen. De medische helden aan de frontlinie moeten we hier in ieder geval thans niet mee lastigvallen. Voor nu vooral een soepel juridisch gemoed en voor de toekomst digitale bezinning, maar vooral: houd vol, komt goed! De dag komt dat in de cursuszaaltjes weer 'live' gedanst en zelfs geborreld wordt. En als afsluitende bezinnende gedachte nog dit: een testament is als een 'mondkapje', je doet het niet voor jezelf, maar voor die ander.

Als gebroeders verwijzen wij naar elkaars Tips van deze week.

EstateTip Review 2020-10 is van de hand van broer Freek, met als titel 'De erfrechtelijke vorm ontbreekt: toch rechtsgevolgen? "De meest haalbare vorm van zekerheid en de redelijkheid en billijkheid"'. Deze EstateTip is hier te vinden.

Tot de volgende keer!

Prof. mr. dr. B.M.E.M. Schols

ScholsBurgerhartSchols Estate Planning

Radboud Universiteit Nijmegen

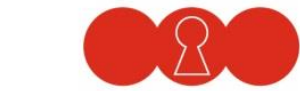

ScholsBurgerhartSchols

www.scholsburgerhartschols.nl

\section{Boomjuridisch}

\author{
Postbus 85576 \\ 2508 CG Den Haag \\ $\mathrm{T}(070) 3307033$ \\ E info@boomjuridisch.nl \\ I www.boomjuridisch.nl
}

Copyright 2020 ๑ AdvoTip

Hoewel uiterste zorg is besteed aan de inhoud van AdvoTip - Erfrecht voor de advocaat aanvaarden de uitgever en de redactie geen aansprakelijkheid voor onvolledigheid of onjuistheid. 